\title{
Research on the Processing and Identification of Joint and Several Liabilities in the Civil and Commercial Law of China
}

\author{
Liping Zhang \\ Oxbridge College Kunming University of Science and Technology, Kunming, Yunnan, China, \\ 650106
}

\begin{abstract}
Keywords: Chinese Civil and Commercial Law, Joint and Several Liability, Processing and Identification
\end{abstract}

\begin{abstract}
Civil and commercial law refers to the civil society system and norms of moral theory, to explore the civil and commercial law and joint and several liability framework is necessary, joint and several liability is a special liability system in civil and commercial law, research and study of the protection of civil power. Civil and commercial law also has civil joint and several liability. As the civil legal system itself is flawed; so in the civil and commercial legal system is more chaotic, and in all the legal system which people have some misunderstanding of the civil legal system, so for our country's civil and commercial law on civil joint responsibility to further Research and discussion This article mainly deals with the defects of civil and commercial law in civil joint liability.
\end{abstract}

\section{Introduction}

Civil and commercial law is also the basic law in our country law; is based on our civil law, civil and commercial law is also an adjustment of economic development of an argument, for civil and commercial law to joint responsibility to deal with economic law according to economic rights distribution. To be investigated and studied to further adjustment, according to the provisions of Chinese civil and commercial law to prove the existence of joint and several liability, it must be civil protection, in this economic recession society, and will inevitably with some of the law on things, and sometimes To work according to national law. In fact, civil and commercial law refers to a kind of protection of the right of things, and joint and several liability is to establish an obligation, in violation of the obligations of the obligations of those who violate the constraints and punishment. To be realistic, there is sufficient evidence to prove the basis of the violator and that the control and punishment, which is our civil and commercial law on the joint and several liability sanctions, in fact, joint and several liability is also under the civil law system of our provisions, so as not to the future economic rights Responsible for the protection of things more detailed, more accurate and clear!

\section{The Responsibility System in Chinese Civil and Commercial Law}

What Are the Responsibilities of Civil and Commercial Law in Our Country? No matter what things do not violate the law, the law is to protect personal property and personal reputation of all things, in fact, the law as early as the ancient times already exist, but in which period has not been comprehensive improvement and adjustment, before also divided into many systems, the ancient times is not to promote equality of all this system, are to promote the strong king; loser for Kou! 
But with the development of the times is now no longer slavery country, and now is to promote the system of equality for all! In today's society for me the law is the king, who violates the provisions of the law, it will be subject to national sanctions, civil and commercial law is mainly in violation of the provisions of the economic system of obligations and conclusions. For example, in this business opportunity, we had to say in advance a good cooperation, we have no contract on this obligation, you do not have to say that this thing is in violation of the law, so I do you say yes In violation of the law, that time the country to find who the people to find who, these are in accordance with the provisions of our Civil and Commercial Law, since the touch will be subject to sanctions, punished; these are inevitable conditions, in fact, the main responsibility system is still reflected In the creditors get full proof and then it is mainly reflected in the joint tort and common risk behavior.

The Joint and Several Liability System. Joint and several liability system in our country civil and commercial law is also plays an invaluable re-use, joint liability system refers to the maximum protection of personal values and creditors of their creditor's rights are fully realized. It is for the protection of personal property safety and economic continued to play a major re-use, in this rapid economic development of society, inevitably the national economy sometimes will be some impact; that is, when the economy is more depressed society will be riots in this Economic crisis at the moment the state staff is to be calm, then the joint and several liability will play a certain role in our country's judiciary, legislation, there are civil and commercial law there will be joint and several liability system, and its important, joint and several liability Sexual legal basis is the guarantee of rights! Is to promote people in the highest rights of individuals by the law of protection, is to witness the people's well-being of life responsibility, at different stages there will be a different joint legal system is to provide to the people in the rights and human rights Aspects of fair treatment to meet, joint and several liability is not alone in the economic system and be reflected in the responsibility of them are also fully realized the value of the joint relationship? People are more emphasis on money and the right of these two things, that this is reflected in the value of self-life things, but to be satisfied at the same time it is impossible, in our modern society, money and rights are sometimes conflicting It is impossible to grasp two important things at the same time, two must have to give up one, two important things cannot exist at the same time. So the joint and several liability is built on the basis of our personal desire.

\section{The Basis for Our Civil and Commercial Law on the Joint and Several Liability}

The Constitution is the first law of our country, and there are many different legal systems in the constitution. As our civil and commercial law also has an immeasurable position and our country population and more, in the legal aspects are very important, the law is to regulate people's behavior habits and sound personality, in many cases our country's law is more Normative and reasonable, the law is based on the country's social order and conditions to improve, civil and commercial law is in a certain economic basis to make practical protection and security, is the identification of personal property, when people will be in the community Material basis is not satisfied so it will make some unacceptable events, and civil and commercial law is for some commercial crime, and sometimes commercial crime is very serious, it can be studied, commercial crime sometimes May affect the economic development of a country, commercial crime is the most serious, which is some means of business and make reasonable sanctions, control! So that more commercial economy will be developed, to be more closely protected, in fact, these are connected to each other; the law is like a rule of meaning, since the violation of the rules, it is necessary to pay the corresponding price, these are inevitable.

Civil law is the study of traditional law, including, civil law, power law, contract law and 
personality tort law and so on all legal neighborhood research work, followed by Chinese civil law is the basic law of Chinese economy, civil and commercial law is also the main The study of Chinese legal and legal system construction and the development of a market economy to obtain a good re-use; since the establishment of Chinese law in the community has also been a great reuse! And once in a university in China has a professor also established the status of civil law, civil law is now also become a lot of civil law school production and textbooks.

The name of the textbook is "the study of the major problems of our civil code" won the "first three hundred" original publication of the project. And civil law is the basic law, commercial law is a special law, civil law is to pay attention to the safety of the transaction, and commercial law is to focus on efficiency, civil and commercial law is to preserve people's behavior normative personality so that we in the bustling world to restrain all irregular behavior Guidelines; under certain conditions to control our thinking and individual rights to be controlled in order to pursue a better life and good things.

Civil law: civil law is to achieve a country's governance capacity and governance embodies the major criteria, is an important manifestation of the country and the nation, but also on our lives have been affected; for today's Chinese civil and commercial law in the civil and commercial activities are very Complex, whether it is the market operation or people's illness and death will be civil and commercial law in the civil law protection, but also on the country's social order and law and order have high requirements, the law to further improve and improve the basic rules and requirements of society, society will Get a comprehensive development, quality of life will be improved. Since the opening of our country, the civil legal system has gained the attention and impetus of the country and has become an indispensable framework in our life. It has also led to a radical change in our country's economy. But also to promote Chinese civil and commercial activities to be the basic follow.

Contract law: the contract law is based on Chinese civil and commercial law to develop, in contemporary society often appear orderly instability of the phenomenon, so in order to protect the legitimate rights and interests of the parties to the contract to develop the relevant legal policy to protect the parties to the contract The promotion of socialism in modern society to be a comprehensive development and construction, but also to promote our life in the conditioning rules to be reasonable arrangements and improvements, according to Chinese contract law of the law of the provisions of the contract for the equality of the main body is the natural person, legal person, between other organizations if you want to make changes must terminate the civil rights relationship agreement, Chinese relevant laws and regulations in the parties to exercise the right to fulfill the two sides must follow the principle of good faith? To fulfill their commitments, in a reasonable condition to sign, otherwise the future will have a bad impact on both sides, after the parties signed to respect each other, respect for the law do not disturb the social and economic order, to be treated peacefully.

In order to improve the country's economic efficiency system, China has established a basic system to safeguard the national economic efficiency, and clearly improve the purchase order and economic order of the social market, and once perfect it. In order to improve the economic efficiency system of the country and the legal rights of the economy on our market we should in accordance with the relevant provisions of a clear material ownership. It refers to the right person in the treatment of the exercise of direct control and arrangements for other exercise rights. If the parties were to sign the treaty when the replacement and change, or to destroy the different treaties! In addition to the statutory must be the consent of the other party to destroy and change, autonomy cannot change or destroy the relevant treaty, which is the exercise of the relevant provisions of the 
right.

\section{Chinese Civil and Commercial Law on the Joint Responsibility Exercise What Kind of Sovereignty}

According to Chinese Guarantee Law, in the guarantor and creditors to fulfill the agreement, when the debtor does not perform the debt If the debtor does not assume the responsibility of the debtor, the guarantor must pay the debtor for the performance of the debt, the guarantor of the guarantee method has a joint guarantee and general guarantee, the parties should be in the contract before the identification of the debtor It should be written that the guarantor and the debtor should bear those joint and several liability, so as not to fulfill the commitments in the future, after signing the contract, the joint and several liability to ensure that the debtor in the contract after the deadline to fulfill the agreed repayment The guarantor may have the joint responsibility or the guarantor repayment, the guarantor in the guarantee of the right to debt the debt after the debt or the package also, the guarantor can exercise the corresponding rights, the debtor is not in accordance with the agreed performance is that these rights the guarantor is able to exercise.

In the joint and several liability in Chinese relevant laws and regulations in causing damage caused by others, should bear joint and several liability. In such a complex society to survive, there are many things to do everything must be careful, as far as possible in the right not so persistent, and sometimes your little selfishness will bring harm to others, when the time will be disposed of in this way Kind of bustling and tempting society to survive must be calm! Must be careful, according to the provisions of the Civil Code, if there are more than two acts of infringement of others, it should bear joint and several liability, a college student due to class in class and classmates a little conflict, afternoon after school and invited classmates in Which place to go to school and his conflict with the students to interrupt the hand, then the parents were to be against the court to sue two students to their children to fight! The parents who have been invited to say that they are not obliged to take responsibility, according to the provisions of the National Civil Law on the law of liability under the law, if the joint implementation of more than two violations, resulting in damage to others, it must assume joint and several liability.

Civil procedure law in our country is also a frequent discovery, and the events are very heavy that in this rapidly changing society, regular riots will occur, in order to control Chinese social order in the governance of our highest people The court put forward the Civil Procedure Law in the civil and commercial law to the town of social order, so that our personal personality is protected; and in our law which provides that if the legal person that he was framed or framed, The local people's court raises the opportunity to justify itself, and if the defendant is prosecuted by the prosecutor, the prosecutor if there is not enough evidence to prove that the defendant is the basis of the offense It shows that the defendant has not caused a crime, generally if the evidence is not enough to be released! This is our national law, our law is to pay attention to evidence, if there is no evidence that the framing of others will be subject to legal sanctions. Therefore, civil law in civil and commercial law in accordance with the relevant laws of our country to make reference, otherwise the event is not established.

\section{Conclusion}

In today's social law is very important for every country, if there is no law, that the whole country should also be a pot of porridge; law is to safeguard the country's law and order, is used to constrain the norms of human behavior and for Chinese civil and commercial law on the joint and several 
liability I believe that our law will make the appropriate treatment, will give the people and the community to make a reasonable and fair explanation and answer, everyone is equal before the law is true, sometimes We say nothing is absolutely fair, in this complex society to live! Sometimes it will inevitably touch the law, sometimes so only to comply with the rules, to comply with social order, so that our homes will wait until the peace, our country will wait until the development and progress; the law will achieve its own value.

\section{References}

[1] Wang Zhu. On the Common Harmful Acts - From the Perspective of the Theory of Objectively Associated Joint Tort [J] Journal of Fujian Normal University (Philosophy and Social Sciences Edition)

[2] Li Jing. Wang Qingting. No definite agreement on the joint and several liability should not be included in the scope of insurance [J]. People's Justice .2012 (11)

[3] Wen Shiyang. Yao Qian. Liability insurance insurance accident theory of reflection and reconstruction [J] Insurance Research .2012 (08) 